NBER WORKING PAPER SERIES

\title{
INSTITUTIONS AND U.S. REGIONAL DEVELOPMENT: A STUDY OF MASSACHUSETTS AND VIRGINIA
}

\author{
Sukkoo Kim \\ Working Paper 13431 \\ http://www.nber.org/papers/w13431 \\ NATIONAL BUREAU OF ECONOMIC RESEARCH \\ 1050 Massachusetts Avenue \\ Cambridge, MA 02138 \\ September 2007
}

I am grateful to Kenneth Sokoloff and Douglass North for the many illuminating conversations which led to this project. I thank David Konig for his helpful advice on U.S. colonial legal history and participants at a conference hosted by the St. Louis Initiative, CNISS and an urban conference at UBC hosted by Bob Helsely for their comments. The views expressed herein are those of the author(s) and do not necessarily reflect the views of the National Bureau of Economic Research.

(C) 2007 by Sukkoo Kim. All rights reserved. Short sections of text, not to exceed two paragraphs, may be quoted without explicit permission provided that full credit, including $\odot$ notice, is given to the source. 
Institutions and U.S. Regional Development: A Study of Massachusetts and Virginia

Sukkoo Kim

NBER Working Paper No. 13431

September 2007

JEL No. H11,H70,N41

\section{$\underline{\text { ABSTRACT }}$}

The development of the American economy was accompanied by significant spatial income inequalities between the northern and southern regions. While many factors contributed to northern industrialization and southern stagnation, an important factor was differences in their institutions. In the North, a democratic institution fostered growth whereas in the South, an oligarchic institution favored status quo. To gain some insights on the nature and causes of the divergence of these institutions, this paper examines the development of political and legal institutions in Massachusetts and Virginia, the two leading states in the North and the South.

\section{Sukkoo Kim}

Department of Economics

Washington University

One Brookings Drive

St. Louis, MO 63130-4899

and NBER

soks@artsci.wustl.edu 


\section{Introduction}

Economic development is often accompanied by growing spatial income inequalities. ${ }^{1}$ In the United States, the shift from an agricultural to an industrial nation coincided with a significant divergence in northern and southern incomes. In the colonial period, when the economy was agricultural and extractive, the wealth per capita was relatively similar in the northern and southern colonies (Jones (1980)). By 1840, however, income per capita in the North, especially in New England where industrialization began, exceeded that of the South (Fogel (1989)). ${ }^{2}$ In the second half of the nineteenth century, as the industrial revolution spread in the North, income per capita between the North and South diverged even more considerably (Easterlin (1960)). Southern incomes finally started to converge toward northern levels in the second half of the twentieth century (Kim (1998), Mitchener and McLean (1999)).

While factors associated with slavery, capital, labor and resource endowments may have contributed to the growth of U.S. regional spatial inequality, the divergence in regional political and legal institutions was also a major contributing factor. ${ }^{3}$ In the colonial period, the North emerged with democratic institutions which fostered trade and development whereas the South arose with plutocratic institutions which fostered agrarianism. In the early nineteenth century, the North experienced a shift in its legal institutions to a judge-based, “instrumental” law which promoted industrial development whereas the South held onto its traditional jury-based, common law which defended the agrarian status quo. Even after independence and the formation of the United States, state political and legal institutions remained diverged through the antebellum

\footnotetext{
${ }^{1}$ See Kim (2007) for a review of the literature on spatial inequality and development.

${ }^{2}$ In 1840, for the free population, the income per capita in 1860 prices in the Northeast was $\$ 130$ as compared to $\$ 105$ for the South; in 1860, the figures were \$183 and \$150, respectively. See Fogel (1989).

${ }^{3}$ See Acemoglu and Robinson (2006), Kim and Margo (2004), Hughes and Cain (2007), and Atack and Passel (1994) for a review of the literature.
} 
period due to federalism and states' rights. ${ }^{4}$ With the outcome of the Civil War, the South faced a significant assault on its institutions but the convergence of their institutions toward those of their northern counterparts did not begin in earnest until the second half of the twentieth century.

Why did political and legal institutions diverge in historically colonial economies such as the U.S. North and South? Scholars have proposed two main classes of explanations. The first class emphasizes the role of historical accidents (North (1990), La Porta et. al (1998a, 1998b), and Glaeser and Shleifer (2002)). From the perspectives of the colonies, because the Spanish, Dutch, French, and the English colonizers brought with them different sets of institutions, their institutions were accidentally determined by the national identity of their colonizers. In general, these scholars believe that regions colonized by the British were more likely to inherit institutions of democracy and common law whereas those colonized by the Spanish and the French were likely to inherit centralized bureaucracies and civil law. ${ }^{5}$

The second class of explanations focuses on the geographic conditions of the colonies. For Engerman and Sokoloff (1997, 2000), the decisive factor was colonial factor endowments. In countries and regions where geography favored small scale farming, democratic institutions were likely to arise whereas in regions that favored plantation economies based on African or native slave labor, institutions based on elite-rule were likely to arise. For Acemoglu et. al (2001, 2002), colonial climate and native density or productivity were important factors. Since few Europeans settled in places with high settler mortality or high native population density, they had few incentives to develop democratic institutions in these colonies.

\footnotetext{
${ }^{4}$ The distinctiveness of Southern politics in the first half of the twentieth century is well documented by Key (1949).

${ }^{5}$ For the United States, Berkowitz and Clay (2006) find that whether a country was settled by a country with a civil law system and was a member of the southern Confederacy during the Civil War had lasting impacts on state courts. They find that courts in these states had less judicial independence and were of lower quality. Michener and McLean (2003) also find that the institution of slavery was negatively correlated with long-run labor productivity.
} 
Whether the geographic distribution of institutions is determined by the identity of colonizers or by local colonial conditions, the establishment of stable political and legal institutions reflects a self-enforcing equilibrium solution to the fundamental dilemma of the state ((North (1981), Acemoglu et. al (2004)). To establish property rights, it is necessary to have a state which has monopoly on violence; however, if the state has sole military power, then it has the incentive to extract rents from society. For North and Weingast (1989), the rise of the Parliamentary rule by oligarchs in Britain in 1688 was associated with a greater commitment by the state to curtail the power of royal prerogatives. For Acemoglu and Johnson (2000), the rise of democratic rule in Britain in 1832 represented a credible commitment by the state to distribute resources toward the masses and was a necessary response to the potential mass rebellion.

To understand the nature and causes of the divergence of U.S. northern and southern institutions, this paper examines the development of political and legal institutions in Massachusetts and Virginia, the two leading northern and southern states. Despite the important variations in political and legal institutions within the northern and southern states, Massachusetts and Virginia were important model states in their respective regions. Since settlers migrated westward along the latitudes, institutions developed in Massachusetts were transplanted into northern states such as Ohio and Illinois whereas those developed in Virginia found roots in southern states such as Tennessee and Alabama. ${ }^{6}$ Thus, an understanding of the institutional developments in Massachusetts and Virginia will provide key insights to unlocking the causes of institutional divergence of northern and southern states.

In this paper, I argue that historical accidents, climate, and factor endowments all seem to have contributed to the divergence of political and legal institutions in Virginia and Massachusetts. Historical accidents, which led to diverging goals of Virginia and Massachusetts

\footnotetext{
${ }^{6}$ See Matthews (1962), Steckel (1983), Meinig (1993) and Kim and Margo (2004).
} 
Bay companies led to significant divergence of demographic structures and political institutions during their early years of colonization. In Virginia, in order to control its workforce largely composed of young male servants and convicts, a highly undemocratic military regime arose. In Massachusetts, however, the religiously homogenous and egalitarian populace rebelled and fought for democratic concessions from the religious elites who feared mob rule.

After these early years, the differences in their climates contributed to the continued divergence in demographic and institutional structures in Virginia and Massachusetts. In Virginia, the extremely high morality rates created an unsettled community which could only be sustained by the continual recruitment of new, poor, young male servants until the death rates stabilized in the eighteenth century. As a stable free white population emerged over time, an important element of democracy was introduced with the election of the Houses of Burgesses; however, many important offices, such as the county justice, continued to be appointed for life. In Massachusetts, a stable community led to a surprisingly quick emergence of a democratic society based on elections on many levels of government. ${ }^{7}$ While important elements of democratic rule were removed by the British government when Massachusetts became a royal colony in 1691, democratic institutions quickly re-emerged after American independence.

Finally, factor endowments contributed to a major divergence in agricultural scale economies in the northern and southern colonies which in turn contributed significantly to the divergence of political and legal institutions in these colonies. In Massachusetts, poor soil led to small scale agriculture, fishing and commerce; in Virginia, however, climate proved excellent for growing tobacco in large scale, especially with the introduction of slavery. Because the land laws

\footnotetext{
${ }^{7}$ Even though Massachusetts did not possess democracy in the modern form defined by the enfranchisement of the entire adult citizenry, it possessed significant early elements of democracy. For Wilentz (2005, p.xix), "democracy appears when some large numbers of previously excluded, ordinary persons - what the eighteenth century called 'the many' - secure the power simply to select their governors but to oversee the institutions of government, as officeholders and as citizens free to assemble and criticize those in office.”
} 
in Virginia based on headrights, unlike those in Massachusetts, enabled the southern elites to accumulate significant amounts of land, an elite landed gentry with strong common economic and political interests emerged in Virginia. Moreover, the institution of slavery itself also contributed to diverging legal developments between the northern and southern colonies. ${ }^{8}$

The states' coercive ability to enforce their laws and policies also played an important role in determining the level of democracy. Since the colonies relied on voluntary militia for their armies, the governor, council and elected officials were acutely aware of their limited military authority over the governed. Rebellion by the free masses was a constant threat. Even in Massachusetts, the elites granted greater levels of democracy only after facing severe threats of rebellion. In Virginia, the potential for mass rebellion led to a greater access to democracy, but this movement was short-lived when the elites regained upper hand with royal military support. In Virginia, the potential for rebellion by poor free whites also lessened over time as their incentives became more and more aligned with the elites under the institution of slavery and as the elites relied less on local militias composed of free whites for social control.

The paper is organized as follows. Section II documents the historical development of political institutions in Virginia and Massachusetts; section III documents the development of their legal institutions. Section IV examines the role of states' rights and federalism on the continued divergence of institutions in Virginia and Massachusetts. Section V explores the causes of institutional divergence and section VI concludes with a summary.

\section{The Political Institutions of Virginia and Massachusetts}

Virginia and Massachusetts were both founded on the principles of royal corporate charters, but in the New World these colonies by necessity formed governing institutions which

\footnotetext{
${ }^{8}$ See Morris (1996),Wahl (1998), Hindus (1980), Higginbotham (1978), and Tushnet (1981).
} 
resembled commonwealths rather than corporations. Yet, even though both of these colonies were founded by peoples of one European nation with common history, culture and background, they emerged with differing political institutions over time. In the early years of settlement, Virginia struggled to form a working political order but eventually emerged with an oligarchic or plutocratic society. In Massachusetts, however, a more democratic form of government arose in a relatively short time. This section presents a selective historical account of the evolution of political institutions in these two colonies. ${ }^{9}$

\section{A. The Development of Political Institutions in Virginia}

The founding of Virginia was based on a royal corporate charter drafted in 1606 for the Virginia Company which contained a mixture of private and royal organizational form. For profit making, the private company planned to establish plantations worked by servants and laborers under contract managed by overseers. The company was given the right to transport settlers, supply provisions and trade goods. For governing, however, the task was entrusted to three councils whose members were appointed by the King. The powers of government and ownership of land ultimately rested with the King who used instructions to give judicial powers to the local council and issued patents to grant land.

In 1607, 104 passengers in three vessels reached the Chesapeake and settled in Jamestown. The settlers were all male: a third to half were designated as gentlemen and the rest were artisans and laborers. By the order of the King, the identity of the local governing council was kept secret until arrival when the identity was to be revealed. The members of the council then chose a president. By most accounts, under the trying conditions of famine, disease and threat from Indians, the council form of government proved to be ineffective. In 1608, when

\footnotetext{
${ }^{9}$ There are many excellent and comprehensive accounts of the histories of political institutions in Virginia and Massachusetts. For example, see Osgood (1904), Morgan (1975), Sydnor (1952), Wall (1972) and Andrews (1934).
} 
many of the council members had died or returned to England, John Smith emerged as the leader who commanded the colony in military style using labor gangs.

In response to the ineffectiveness of the council government, the Virginia Company requested and was granted a new charter by the King in which the company had complete control over the colony. In London, the company took steps to run the colony under a military regime initiated by Smith. ${ }^{10}$ The new leaders of the colony were old soldiers. Between 1611 and 1618, the company ruled the colony through a governor who exercised absolute powers. ${ }^{11}$ The government forged by the first governor, Lord De la Warr, his deputy Sir Thomas Gates, and subsequent deputy Sir Thomas Dale, was a code of military rule known as Dale’s Laws. The settlers continued to work in gangs and were deprived of protection under the common law. ${ }^{12}$

When the gang labor system and military rule failed to bear any fruit in the New World, the Virginia Company in 1618 re-organized its governing structure and introduced a charter of grants and liberties. The general assembly, which possessed the powers to make laws, was composed of the governor and council, who were chosen by the company as before, but it now also included two Burgesses from each district who were elected. In June 19, 1619, 22 Burgesses were elected for the first time. While evidence on the workings of the assembly is scant, it is

\footnotetext{
${ }^{10}$ Shea (1983, 13-15): “Back in London the Virginia Company began to take steps to improve the colony’s fortunes along the militant lines Smith had initiated... the second experiment was modeled to some degree after contemporary English military expeditions to Ireland and the Low Countries... The leaders of this second phase of colonization were 'excellent old soldiers' who had served with distinction in Ireland and 'that university of warre' the Low Countries... Virginia’s military regime was unique in American history.”

${ }^{11}$ To improve the conditions in the colony, a decision was reached near the end of 1609 "to appoint a single head entrusted with exceptionally large powers. The company made up its mind to try a new experiment by sending to America a single and absolute governor, with authority so extensive as to make him almost a dictator for life.” Andrews (1934, p.107).

${ }^{12}$ Morgan (1975, p.80) wrote: "The Laws prescribed death for variety of crimes, including rape, adultery, theft, lying, sacrilege, blasphemy, or doing or saying anything that might 'tend to the derision' of the Bible. On a more practical level, in order to increase the livestock which had by this time been brought over, the Laws made it death to kill any domestic animal, even a chicken. It was also death, in weeding the garden, to take an ear of corn or a bunch of grapes from it, death too to trade privately with anyone on the ships that came to the colony. And, the punishments were inflicted with an arbitrary rigor that became a scandal. For stealing two or three pints of oatmeal a man had a needle thrust through his tongue and was then chained to a tree until he starved.”
} 
doubtful whether Virginia achieved a fully working form of government during this period. Nevertheless, the election of the Burgesses signaled a significant turning point in Virginia history. It marked the beginnings of a two-tier plutocratic society where access to political participation was open to the elites but closed for most of the masses. ${ }^{13}$

When the financially troubled Virginia Company was dissolved by the King in 1624, Virginia became a royal colony and the King appointed the governor and the council of the general assembly. Given the distance from England and a the lack of a royal standing army, however, the royal governor could not overrule the colonists on important matters. The Virginians made up of the Houses of Burgesses and the council were able to effectively legislate on matters of taxes and law. As the Virginia colony stabilized and grew over the seventeenth century, the government of Virginia evolved into its mature colonial form and formed political boundaries in counties and parishes.

More than the transition to a royal colony, the introduction of tobacco seeds of the Spanish West Indian variety by John Rolfe in 1617 had a major impact on the social organization of Virginians. With the tobacco boom of the 1620s, immigration of male indentured servants and share tenants increased. Under the headright system introduced in 1618, a settler who came on his own or who paid the transportation of someone else was entitled to 50 acres. In these early years, given the abundance of land, the societal division arose in terms of the accumulation of servants. The growing of tobacco was both intensive in land and labor, but labor was scarce. Evidence show that the elites were able to acquire numerous indentured servants, often by illegal

\footnotetext{
${ }^{13}$ Morgan (1975, 124): "The company in 1618 had inaugurated a popularly elected representative assembly, but the effective power remained in the governor and his council. By no coincidence, the council consisted almost entirely of men holding large numbers of servants... These men, with a more than average interest in controlling the labor force, were thus enabled to maintain their personal ascendancy not only over their servants but over all lesser men. Whether operating under the company or, after 1625, under the king, they met every challenge to their authority with a rigor not exceeded by what we know of the earlier absolute government of John Smith or Thomas Dale.”
} 
means. The muster of inhabitants in 1625 show that the officers of the Virginia Company each held 10 to 39 servants. ${ }^{14}$

The elites were able to accumulate wealth and hold political power, but the basis for their power was precarious since they relied on local militias to enforce their laws. As mortality rates stabilized, an increasing share of the population was composed of free single males who once were servants. In the early seventeenth century, election of the Houses of Burgesses were held infrequently at the discretion of the governor; however, as free whites became more numerous and rebellious, Governor Berkeley was forced to hold new elections with greater access to voting. ${ }^{15}$ In the election of 1676 , the free whites were able to vote into office a large share of their choices. However, this movement toward greater access was short-lived. When the Bacon’s rebellion collapsed, the elites re-established their political authority, confiscated the property of those who rebelled, and re-established the status-quo of elites.

The introduction of slavery solidified the elite rule based on the ownership of land and slaves rather than on servants. In this period, a mature, stable, plutocratic society emerged based on planter elites (Kulikoff (1986)). Prior to the eighteenth century, based on the identity of justices in tidewater Maryland, Kulikoff finds that justices were highly varied in background. However, by the mid-eighteenth century, the justices and burgesses were dominated by the planter gentry. In the late seventeenth century, Virginia justices and burgesses, as well councilmen, used their public offices to patent thousands of acres of frontier land. By 1705,

\footnotetext{
${ }^{14}$ Morgan (1975, 123-4): "It seems that while the Virginia Company was failing in London, a number of its officers in the colony were growing rich. In order to do so, they not only rendered less than faithful service to their employers; they also reduced other Virginians to a condition, while short of slavery, was also some distance from the freedom that Englishmen liked to consider as their birthright. The company in 1618 had inaugurated a popularly elected representative assembly, but the effective power remained in the governor and his council. By no coincidence, the council consisted almost entirely of the men holding large numbers of servants... Whether operating under the company or, after 1625, under the king, they met every challenge to their authority with a rigor not exceeded by what we know of the earlier absolute government of John Smith or Thomas Dale.”

${ }^{15}$ In order to keep the same men in office in the House of Burgesses, Governor Berkeley did not call for a general election for 15 years between 1661 and 1676 (Andrews (1934, 247)).
} 
three-fifths of Virginians who owned 2,000 or more acres of land were justices or burgesses. By the mid-eighteenth century, strong political dynasties formed. For example, more than a quarter of the 1,600 justices appointed in Virginia between 1757 to 1775 belonged to only 55 patrilineages. The gentry used entail and marriage to consolidate the political ruling class.

The governor usually chose council members from the top families of the planter gentry. Sydnor (1952) finds that a small number of families enjoyed the powers of this office. Only 57 family names appear from 1680 to the Revolution as council members; nine families account for almost a third of the councilors during this century. The House of Burgesses was the only elected body in Virginia, but the election was also controlled by the elite gentry. ${ }^{16}$ Election dates were chosen by the governor and two members were elected from each county and one each from Jamestown, Williamsburg, and the College of William and Mary.

In Virginia, the county became the most important level of government for most people. Moreover, unlike Massachusetts, where local town officials were elected by freemen, county officials in Virginia were appointed and these officials possessed broad legislative, executive and judicial powers. ${ }^{17}$ County justices, who individually settled disputes on small debts and collectively composed the county court, were appointed to serve for life by the governor. In practice the justices provided the governor with a nominee who the governor then commissioned. The county justices not only decided on issues of law but they also set tax rates, allocated county funds, and managed roads and bridges. Just as importantly, the county justices appointed local government officials, such as the sheriff (who enforced laws, managed jails, collected taxes, managed the treasury, and conducted elections), coroner, militia officers below rank of brigadier, and tobacco inspectors.

\footnotetext{
${ }^{16}$ See Sydnor (1952), Griffith (1968), and Morgan (1975).

${ }^{17}$ Most scholars believe that the government in Virginia was undemocratic (see Porter (1947), Sydnor (1948, 1952), Morgan (1975)). However, Brown and Brown (1964) contend that Virginia was much more democratic.
} 


\section{B. The Development of Political Institutions in Massachusetts}

The Massachusetts Bay Company, formed in 1629, was based on a corporate charter, much like those of the earlier Virginia Company except in one important aspect. ${ }^{18}$ In all the previous colonies, they were managed chiefly for profit and controlled by proprietors in England and the colonists were not entitled to the right of self-government. For Osgood (1904), the founding of the Massachusetts Bay colony marked a major change where the government of the plantation was transferred to those who lived in the colonies. For governing, the general court, prior to their departure in England, elected Winthrop as governor of colony and company, Dudley as deputy governor, and 18 other assistants. For profit making, the company created a temporary trusteeship known as undertakers who assumed control of assets and liabilities of the joint stock. Undertakers were to receive profits from the fur trade, the salt-making monopoly, and the transportation of passengers and goods.

In 1630, approximately 700 individuals in 11 ships sailed for New England. When the settlers arrived in Massachusetts Bay, they intended to work and live as a corporate body in one location where each settler received an allotment of land based on their investments. ${ }^{19}$ Within months of their arrival, however, these plans were abandoned as settlers dispersed into nearby areas, formed separate towns and claimed land for themselves. These early settlements were established without the explicit authority of the general court. In addition, as the commercial element of the Massachusetts Bay Company quickly disappeared, trade was authorized to take place in private hands and the colony became a de facto commonwealth.

\footnotetext{
${ }^{18}$ The discussion on Massachusetts will concentrate on the Massachusetts Bay colony. Even though the Plymouth colony was founded earlier, the larger Massachusetts Bay colony was more influential for political developments in Massachusetts. In 1691, these two colonies joined to form Massachusetts. See Osgood (1904).

${ }^{19}$ Rutman $(1965,44)$ “... the company offered large tracts of land to actual investors in the enterprise, two hundred acres per fifty pounds invested. The fact that an individual transported himself, his family, and his servants to the settlement was, in itself, considered as an investment and also subject to return. Hence, those actual purchasers of the company's stock who traveled to the New World were to receive fifty acres for themselves and every member of their family...”
} 
In Massachusetts, unlike Virginia, a democratic government based on regular elections arose in a relatively short period of time. Immediately, Winthrop and his associates were forced to recognize the new towns, fix their boundaries, and give them the rights to grant land. They were also forced to relinquish oligarchic control as large number of colonists applied for admission as freemen. In 1634, the colony declared that the freemen alone had power to admit new freemen, make laws, appoint officers, raise money and grant lands in the commonwealth of Massachusetts. The General Court, composed of two elected deputies from each town, was authorized with legislative powers; the governor and the assistants elected by freemen retained executive and judicial powers.

The General Court also took control over unoccupied lands and claimed the exclusive rights to grant land and create townships (Akagi (1924), Martin (1991), and Price (1995)). Prospective settlers, called proprietors, petitioned the General Court for a grant of land. ${ }^{20}$ Although the land was granted freely, starting a town was an expensive and complicated affair (Martin (1991)). Town promoters, often politically connected and experts in Indian affairs, coordinated the founding of towns and received land for their services. The General Court surveyed the land, coordinated its purchase from the local Indians, and then granted it to proprietors who were given exclusive rights to distribute land and admit new town members. The General Court also gave towns a considerable degree of local political control and in 1641, selectmen were officially designated as chief administrators of local affairs.

\footnotetext{
${ }^{20}$ The town proprietors allocated land for house lots, meadow lands for hay and grazing, and upland for cultivation. Land was not divided equally and the amount of acreage allocated depended upon variety of considerations such as wealth, occupation, family size, and participation in the purchase of the land. The average initial allocation of land was relatively small in many towns and averaged fewer than 30 acres per proprietor. In most towns, a great majority of land was set aside for future division and each proprietor was given shares of this undivided land. As towns increased in size, new town members became non-proprietors with no rights to undivided land. In many towns, conflicts arose between proprietor and non-proprietors over the control of land and the town government. By the early eighteenth century, the General Court gave the rights to the undivided land to the original proprietors but the governing body of towns included non-proprietors.
} 
In Massachusetts, democratic town governments became the most important local institution. Once a year in March, freeholders met to elect local town officials: clerk, selectman, treasurer, constable and many lesser offices. Since the voting procedure was left to the discretion of towns, there was a great deal of variation in electoral practices. Over time, the elections were handled by a moderator, used written but not secret ballots, and became more formal (Cook (1976)). Yet, towns were not free of disputes. Because towns were often ill-equipped to settle and enforce disputes, Konig (1979) argues that the quarterly courts were an indispensable institution for establishing social order throughout the colony. ${ }^{21}$

The continual movement toward a democratic government in Massachusetts occurred under considerable dissension and debate (Breen (1970)). For a colony founded to form a religious community, the political separation of church and state was a major issue, especially in the early years. Related to the idea of the religious and moral authority of the ruler was whether political leaders possessed wide discretion or possessed delegated authority. While dissension on the right form of government never dissipated, political debates increasingly became more secular and were on topics of property and liberty rather than of scripture and religion.

With the return to power of the Stuarts in 1660 in England, the Massachusetts colony faced a major challenge to its autonomy. In an abrupt change of policy, the King and the Board of Trade annulled the original charter in 1684 and established royal political authority over the colony. Massachusetts and other northern colonies were consolidated into a single Dominion of New England and placed under the rule of a royally-appointed governor. Representative

\footnotetext{
${ }^{21}$ The colonists, according to Konig (1979), drew upon their English experience and created a judicial system based on the patterns of English county, the borough justices of peace, and courts of quarter sessions. Because some of the early leaders of the Massachusetts Bay colony, John Winthrop and Richard Bellingham, were justices of peace in their respective home counties in England, the Puritan reformers placed great responsibility on the justices of peace. Over time, however, the effectiveness of these justices of peace declined as communities became less cohesive and the county justices who met once a quarter became much more effective.
} 
government and town authority were significantly curtailed. While an elected House of

Representatives became the legislative body, and nominated the members of the upper house, the governor, selected the Council from the representatives' list of nominees and his signature was necessary for an enactment to became law.

The period under royal rule between 1684 and 1776 was a period of uneasy compromise. When property rights and representation were significantly undermined as were under the rule of the royal governor Edmund Andros in 1686, the colonists rebelled by arresting Andros thereby setting the boundaries of what they would allow. After the Andros affair, the royal governors learned to work within the limits of their authority, but for colonists who developed their own political institutions based on electoral representation, the royal government never gained full legitimacy. In the eighteenth century, as the interests of England and the American colony continued to diverge, the colonists who without representation on major policies rebelled to recover their democratic institutions developed in their early years of colonial history.

\section{The Legal Institutions of Massachusetts and Virginia}

In the colonial period, the legal institutions in Virginia and Massachusetts were local, jury-based, and founded on the common law tradition of England (Nelson (1975)). ${ }^{22}$ To the extent that there were divergent trends in these two colonies, they may be accounted for by the fact that early colonists did not bring with them the English common law of the King's court, but rather the customary law of English local courts which varied by region (Groebel (1931), Allen (1981)). Moreover, in Massachusetts, there seems to be some evidence that local colonial

\footnotetext{
${ }^{22}$ The Anglo-Saxon English common law, compared to Roman Civil Law, was more diffuse in its historical origin and application, reflecting the diversity of England after the end of Roman occupation. Common law operated on two tiers: at the royal, aristocratic level, common law system evolved into a complex body of rules interpreted by trained lawyers and judges; at the local level - counties, manors, and boroughs, common law rested on longestablished customary practices (see Hall (1989)).
} 
circumstances may have led to changes in the application of common law (Konig (1979)). On the other hand, in Virginia, courts were presided by country justices with little education in law for most of the colonial period (Roeber (1981), Konig (1992), Miller (1994)).

Property law in the American colonies, especially in New England, according to Priest (2006), may have diverged significantly from that of English law in its alienability. As the property law in England was designed to protect the devolution of real property, an individual's title to land was protected from the claims of unsecured creditors. In New England, however, the colonial legislatures moved to reject English protection of real property and, in 1732, the Parliament endorsed this movement by enacting a statute known as the Debt Recovery Act. Thus, in Massachusetts and elsewhere, land became equivalent to any other property. While the act was designed to apply in all the American colonies, evidence suggests that Virginia may have remained an important exception. In Virginia, the use of primogeniture, entail and local juries provided an important mechanism for protecting real property from creditors. ${ }^{23}$

In the first half of the nineteenth century, legal scholars believe that the American legal system went through a more fundamental transformation. In this period, the legal system went from jury-based, common law to judge-based, “instrumental” law (Nelson (1975) and Horwitz (1977)). ${ }^{24}$ While the evidence of the geographic divergence of legal systems between Massachusetts (North) and Virginia (South) is relatively scant, a growing number of scholars

\footnotetext{
${ }^{23}$ Differences in inheritance laws between Massachusetts and Virginia provide additional evidence for the divergence of legal systems between these two colonies during the colonial period. While Virginia and the southern colonies (including Rhode Island and New York) practiced the common law of primogeniture widely practiced in England, Massachusetts and other New England colonies adopted male multigeniture, a practice found in County of Kent. Since primogeniture would prevail without legislation, multigeniture required an act of the colonial legislature (Alston and Shipiro (1984)). Virginia adopted primogeniture and entail which significantly reduced the potential devolution of property. While Keim (1968) finds that only a small percentage of property in Virginia was subject to entail, Brewer (1997) argues that Keim's estimates are flawed and that a larger share of property may have been subject to entail.

${ }^{24}$ To the contrary, Simpson (1979) and Schwartz (1981) argue that the Horowitz thesis is unfounded in the data. Both of these scholars claim that there was no radical change in law between the late eighteenth and the early nineteenth centuries.
} 
believe that Massachusetts was a leader in this transformation whereas Virginia remained a laggard (Ely and Bodenhamer (1984), Konig (1992), Miller (1994), among others). ${ }^{25}$ Cases from Massachusetts (and New York) state supreme courts were cited, but those from Virginia and other southern states were ignored (Friedman (1984)).

\section{A. Colonial Law in Massachusetts and Virginia}

For Nelson (1975), pre-revolutionary law in Massachusetts was characterized by a legal system based on the British common law tradition of local communal consensus. One of the most important features of pre-revolutionary law was that the jury ruled both as law and fact. ${ }^{26}$ Because norms of local communities varied, and since local juries did not provide written commentaries on their decisions, jury-based law did not provide a sound basis for a uniform law over a wide geographic area. Moreover, the common law concept of fair exchange, often determined by the ethical norms of a local community, subjected the enforceability of a contract to local community standards of fairness. Likewise, under common law, corporations were believed to be created by the legislature for public rather than for private purposes and their charters could be amended or abolished for the communal purposes of a community.

Common law property rights gave the land owner the right to prevent the use of any neighbor's land that conflicted with his own quiet enjoyment. The natural use and prescription doctrines limited the use of a property to natural uses (agriculture) and gave monopoly rights to

\footnotetext{
${ }^{25}$ Campbell (1975) and Huebner (1999) argue that, while Virginia's legal system was not as advanced as that of Massachusetts, the legal system in Virginia was also moving away from common law to instrumental law.

${ }^{26}$ Nelson (1975, 3-4): “The fact that juries rather than judges regularly decided law applicable to litigated cases tells us much about pre-Revolutionary law and society. It demonstrates first that the law applied in the towns of Massachusetts on a day-to-day basis was not the product of the will of some distant sovereign; on the contrary, jury verdicts given without benefit of binding and unambiguous judicial instructions must have reflected jurors' experience either with common law as it had been customarily applied in their towns or with other customs that their towns observed as law. The power of juries over the law also tells us that the legal system did not serve as an instrument for majoritarian resolution of group conflict and the enforcement of the will of the most powerful group... In a legal system in which juries have the power to find the law, whatever disputes arise cannot be resolved by mere majoritarian fiat but must be resolved by a process of consensus building that produces legal rules acceptable to a broad base of society as a whole.”
} 
the first developer of a resource. Horwitz (1977) argues that property rights under common law hindered development. These laws raised the costs of building roads, canals and railroads as well as building mills for water power. For example, the natural use doctrine did not allow the alteration of water flow except in its natural channel and any use of water that conflicted with the interests of other land owners along the stream was an unlawful invasion of property.

Common law principle of contract was based on the fairness doctrine that sought to protect people from unfair exchanges. The fairness standard, however, created uncertainty in contractual transactions. Under the fairness doctrine, if two parties agreed on a contract on the delivery of a good at a specified price, the contract could be nullified by the courts if the contract was deemed to be unfair to one party. Thus, the enforceability of a contract was at the discretion of the courts rather than bounded by the agreement drawn up by individuals. ${ }^{27}$ Since the standards of fairness may differ between jurors in different communities, the fairness principle raised the costs of transactions across localities. In addition, the fairness standard limited the negotiability of a contract. If individual A gave a promissory note to B, who transferred the note to $\mathrm{C}$, then $\mathrm{C}$ could not sue $\mathrm{A}$ in the event that the contract was breached.

\section{B. Post-revolutionary Law in Massachusetts}

Between the American Revolution and the early nineteenth century, the legal institution in Massachusetts was transformed from one based on preserving status quo and traditional social stability to one based on free will, uniformity and predictability for economic exchange (Nelson (1975), Horwitz (1977)). Between 1804 to 1809, reforms were enacted to limit jury power. The

\footnotetext{
${ }^{27}$ Horwitz (1977, 167): "What we have seen of eighteenth century doctrines suggests that contract law was essentially antagonistic to the interests of commercial classes. The law did not assure a businessman the express value of his bargain, but at most its specific performance. Courts and juries did not honor business agreements on the face, but scrutinized them for the substantive equality of their exchange. For our purposes, the most important consequence of this hostility was that contract law was insulated from the purposes of commercial transactions. Businessmen settled disputes informally among themselves when they could, referred them to a more formal process of arbitration when they could not, and relied on merchant juries to ameliorate common law rules.”
} 
law finding function was shifted from the jury to the judge and the jury's task was relegated to fact finding functions such as determining the credibility of the witness or weighing the probability of competing testimonies. Moreover, the common law of contract was replaced by the "will theory" of contract. What mattered was whether individuals agreed on the terms of the bargain rather than whether the agreement was fair, foolish or inequitable to a party. These developments reduced the uncertainty of contractual exchanges and the costs of market transactions.

The will theory of contract affected many areas of economic activity. In the sale of land, individuals were free to devise contracts which were binding in courts. The sentiment for will theory was expressed by Chief Justice John Marshall: "To deny the power of two individuals, capable of acting for themselves, to make a contract for the purchase of land and sale of lands defeasible by the payment of money at a future date, or, in other words, to make a sale with reservation to the vendor a right to repurchase the same land at a fixed price and at a specified time, would be to transfer to the Court of Chancery, in a considerable degree, the guardianship of adults as well as of infants.”

In pre-revolutionary law, caveat emptor did not apply. For example, if two people bargained over a horse and the horse died subsequent to exchange, the buyer could sue the seller for damages. In post-revolutionary law, the will theory of contract increased the importance of caveat emptor. Thus, even if a person purchased a defective good, the buyer was now responsible for his actions. By limiting the buyers' right to sue for decline in the quality of goods after purchase, caveat emptor reduced the transactions costs of market exchanges.

Common law viewed corporations as similar to municipalities which were created for public rather than private purposes. In the early nineteenth century, Massachusetts recognized the 
private nature of corporations, upheld the private contractual nature of the corporate charter, and provided limited liability to managers and shareholders. In Ellis v. Marshall (1807), the Massachusetts Supreme Judicial Court made a firm distinction between public and private corporations. In deciding that a private corporation was distinct from a public corporation, the court effectively limited legislative authority over corporations. ${ }^{28}$ Likewise, in Wales v. Stetson, the Massachusetts Supreme Court ruled that private corporations were closer to contracts than municipal governments. ${ }^{29}$

In Gray v. Portland Bank (1807) the Massachusetts Supreme court established that the officers of a corporation had fiduciary duty to its shareholders. In the early nineteenth century, it was not clear whether a breach of contract or in tort could be brought against a corporation rather than its officers who performed the injury-creating act. In Gray and Riddle v. Locks and Canals on Merrimack River (1810), the court ruled that corporations could be sued for damages. However, while the corporation could be sued for damages, the court also gave the officers and shareholders of the firms limited liability. In Nichols v. Thomas (1808) the court ruled that owners were not personally liable for the debts of the firm.

In Massachusetts, the state legislature played an important role in eroding the common law vested property rights through enacting mill acts in the early nineteenth century. The

\footnotetext{
${ }^{28}$ In this case, Front Street Corporation, consisting of all landowners of land over which a street would pass was given power to assess its members for the making of a street in Boston. However, Marshall, the defendant, refused to pay and his adjoining land was sold at auction to pay for the deficiency. Ellis bought the land and then sued in ejectment to oust Marshall. In this case, Justice Parker ruled that the Front Street Corporation was a private rather than a public firm, such as one that might have provided common sewers. The court ruled that the charter of the Front Street Corporation became void when Marshall refused membership. The Ellis case was prominently cited in the Supreme Court case of Dartmouth College v. Woodward (1819).

${ }^{29}$ In Wales, the Blue-Hill Turnpike Corporation sued Stetson for passing without paying a toll and ripping down a gate. Stetson argued that a general act passed by Massachusetts in 1805 prohibited turnpike corporations from erecting gates on pre-existing roads. However, the Blue-Hill Turnpike Corporation had been chartered in 1803. Justice Parsons ruled if favor the Turnpike Corporation: "We are satisfied that the rights legally vested in this, or any corporation, cannot be controlled or destroyed by any subsequent statute, unless a power for that purpose be reserved to the legislature in the act of incorporation.” Wales was the primary precedent for Dartmouth College v. Woodward (1819).
} 
foundation of common law was the view that property owners had absolute dominion over their land. ${ }^{30}$ Because the development of mills, water power or transportation often impacted negatively on adjacent private properties, the hold-up costs associated with vested rights doctrine raised the costs of development. The mill acts lowered the costs of litigation by allowing the owner to flood a neighbor's land and pay an annual compensation specified by the act. Thus, the legislature reversed the common law rule that flooding the land of a neighbor created an injury and nuisance (Hall (1989)).

The state legislature also used the power of eminent domain to shift property rights of externalities to the builders of roads, canals and railroads. The legislature and the courts recognized that the potential costs of common law damages for the building of roads, canals, and railroads were substantial. Under common law, every property owner along the transportation route could potentially sue for damages. The power of eminent domain provided immunity to private companies that built large public projects. Eminent domain, like the mill acts, undermined the traditional vested rights of property guaranteed under common law.

\section{Post-revolutionary Law in Virginia}

While the study of laws and legal systems in Virginia is not as developed as that of Massachusetts, scholars generally believe that the legal system in Virginia continued to champion the English common law traditions based on local juries (Miller (1994)). ${ }^{31}$ Unlike

\footnotetext{
${ }^{30}$ Before the nineteenth century, the common law view of water was a natural flow rule which restricted the uses of water for domestic and agricultural purposes. Beyond the natural use of water for supporting humans and animals, common law ruled that water flows and ought to flow, as it has customarily flowed, and that every man has a right to have the advantage of flow of water in his own land without diminution or alteration. In the early nineteenth century, a new view of water rights emerged. "Under the influence of the mill acts, men had come to regard property as an instrumental value in the service of the paramount goal of promoting economic growth (Horwitz (1977, 4751)). See Steinberg (1991).

${ }^{31}$ Miller (1984, ix): “This work runs counter to the view of the law during the early Republic from works - most importantly Morton J. Horwitz, The Transformation of American Law, 1790-1860 ... - that, by concentrating on New York and New England sources, have contended that America moved away from an agrarian and amateur or popular law to a commercial and professional law allied to business interests... Even if Morton Horwitz is right that
} 
Massachusetts which transformed its legal system to foster industrial development, Virginia used its legal system to protect the landed interests of the elites. Virginia’s legal system inhibited development in a variety of ways: it favored debtors over creditors, favored landlords over tenants and sharecroppers, was slow to adopt caveat emptor or recognize private corporations, and adhered to "vested" rather than legislative rights (Ely and Bodenhamer (1984)).

In Virginia, unlike Massachusetts, Miller (1994) argues that the legal system continued to advance the traditional rights of the jury over the judge. Because a large share of civil suits between 1785-1825 involved British debt cases, the local jury system provided effective means to delay and reduce debt claims. The judges role in Virginia was only to answer a question concerning a specific point of law if requested. A judge instructing the jury was seen as an invasion of the jury's province; judges in Virginia were not allowed to sum up the evidence at the end of the trial. In a series of cases brought to the appeals court on the relative roles of juries and judges, the Virginia appellate courts consistently upheld the traditional, common law rights of the jury.

Due to the lack of systematic legal studies, it is difficult to determine to what extent Virginia's contract law was based on the common law fairness doctrine rather than the will theory introduced in Massachusetts. At best, the evidence is mixed. In Groves v. Groves (1790), Virginia's lower court appeared to adopt the will theory of contracts by ruling for expectations damages in connection with a buyer's action for securities, but the Virginia Court of Appeals subsequently reversed this decision (Horwitz (1977)). In the sale or hiring out of slaves, Wahl (1998) finds continued acceptance of the common law fairness doctrine, but Morris (1996)

the law became a means for transforming society and developing the economy of New York and New England, the evidence indicates that this sort of transformation was not occurring in Virginia, even in internal improvements (such as improving navigation and building canals).” 
argues that, except for the Carolinas and Louisiana, southern judges adopted caveat emptor by the end of the eighteenth century. ${ }^{32}$

In Virginia, corporate charters were often seen as a public good and the legislature either reserved the power to amend the charter or, if not, limited the duration of the corporation (Campbell (1975)). ${ }^{33}$ In the well-known case of Currie’s Administrators v. Mutual Assurance Society (1809), Justice Spencer Roane ruled that the legislature could amend the original charter of the corporation. ${ }^{34}$ The Mutual Assurance Society, an insurance scheme where members insured each other, was originally chartered by the legislature in 1794 . However, in 1805, the legislature amended the charter under interest group pressure. Since country subscribers were subsidizing town subscribers who faced great danger of fire, the legislature separated the subscribers into the two groups. In 1805, Currie, a town dweller, brought a suit against the Society claiming that the 1805 act violated the society's original charter by increasing rates without consent.

Roane upheld the 1805 legislative act and sided against Currie. Roane’s verdict is interesting on two important accounts. First, Roane’s decision is consistent with the common law theory of contract. Roane’s decision was fair in the common law sense because the rural residents should have contributed less than the urban interests and they should have been

\footnotetext{
${ }^{32}$ Because Virginians tried to tie slaves to land, slaves were considered as realty for some purposes for most of the eighteenth century (Morris (1996)).

${ }^{33}$ While Ely and Bodenhamer (1986) believe that southern law diverged from northern law, they argue that southern courts enforced caveat emptor and accepted the private contractual nature of corporations.

${ }^{34}$ Spencer Roane served on Virginia's Court of Appeals, the highest appellate court, between 1794 and 1822. Roane came from a wealthy Tidewater gentry family. Like many wealthy Virginians, he was educated at William and Mary where he received an English legal education based on the writings of Littleton, Coke and Blackston. He married the daughter of Patrick Henry, inherited a large estate from his father, acquired more land and slaves, and became a Tidewater planter himself. "English precedents and principles held a place of particular importance in Roane's decisions... In Roane's view, English authorities stood on equal footing with decisions of Virginia's courts... Hearkening back to the great legal tradition of English legal scholarship, Roane cited Blackstone and others in support of adherence to such long-established precedent... Roane's conception of the judicial role combined a belief in strong, independent, authoritative judiciary with a devoting to the wisdom of the ages as expressed through the common law (Huebner (1999, 22)).”
} 
protected from unfair exchanges. However, under the will theory of contract, the court would have upheld the original contract, even if it turned out to be unfair. Second, Roane did not believe in the sanctity of private corporations. Since corporations were created by legislatures for public rather than private purposes, the Mutual Assurance Charter was not sacred nor inviolate. Thus, the legislature was well within its rights to amend the charter, especially if it served the public.

In Virginia, the rights of property favored agriculture rather than transportation and manufacturing. The legal system through the use of local juries continued to uphold the traditional common law rights of property which raised the costs of industrialization. Unlike Massachusetts, where the mill acts and eminent domain were used by the legislature and the courts to transfer the rights of land use to transportation companies and manufacturing firms, the opposite remained true in Virginia. Whereas statute laws minimized compensation to affected land owners in Massachusetts, the local juries determined damages to landowners in Virginia. ${ }^{35}$

Finally, scholars believe that Virginia and the South promoted a tradition of violence and extra-legal methods of enforcing behavior (Ely and Bodenhamer (1984), Friedman (1984)). In his study of criminal justice in South Carolina and Massachusetts, Hindus (1980) argues that South Carolina promoted extra-legal and informal authority whereas Massachusetts took strong steps to limit extra-legal authority. In Virginia (like South Carolina), extra-legal authority of

\footnotetext{
${ }^{35}$ Crenshaw and Crenshaw v. Slate River Company (1828) provides an interesting eminent domain case in Virginia. In 1819, the state legislature created the Slate River Company and gave it eminent domain to open up navigation of the Slate River. The legislature ordered five mills on the river to build locks at their milldams for boats and if the millers failed to do so, the Slate River Company was entitled to destroy the milldams for being a nuisance in a public waterway. Ashbury and Thomas Crenshaw, the owners of the mills, brought a suit against the company. When the case went to the court of appeals in Virginia, the court ruled against the Slate River Company. The ruling is revealing in its emphasis on the power of local government and local juries. Although the state legislature had full authority to take land for public use, the court ruled that the county's eminent domain powers, which granted the right to build mills on the Slate River, took precedence over the state's rights. In response, the state legislature did nothing (Miller (1994)). See Majewski (2002) for a similar case involving Shadwell Mills and Rivanna Navigation Company and James River and Kanawha Company in Albemarle County, Virginia.
} 
planters was consistent with localism. In addition, slavery condoned violent behavior of whites such as whipping even though brutality of masters was restricted (Wahl (1998)).

\section{States’ Rights and Federalism}

The political and legal institutions between the northern and southern states continued to diverge after the American independence because the U.S. Constitution granted significant rights to states. While all states invoked "states' rights" when it suited their purposes, these rights were held more strongly by southerners. For Madison, the Constitution established a system of divided sovereignty between the federal government and state governments; he wrote: "its (federal) jurisdiction extends to certain enumerated objects only, and leaves to the several States a residuary and inviolable sovereignty over all other objects (McDonald (2000, 20)).” The Bill of Rights was introduced to protect states' rights and Jefferson called the Tenth Amendment "the foundation of the Constitution"; it provides that "the powers not delegated to the United States by the Constitution, nor prohibited by it to the States, are reserved to the States respectively, or to the people." Consequently, the constitution was not adopted by a national vote but rather by a convention in each state to replace its own previous constitution (McDonald (2000, 24)).

The sentiment for states' rights was the strongest in Virginia. When John Adams, a pronationalist, was elected president, Virginians reacted strongly. In response to the Alien and Seditions Acts, which made it illegal to criticize the federal government, Madison and Jefferson wrote the Virginia and Kentucky Resolutions in 1798. In these resolutions, Madison and Jefferson declared that the Constitution was a federalist compact and that state governments have the right to declare offensive federal laws illegal in their lands. In the early antebellum period, 
Virginia's call for its state's rights was only muted by the fact that a Virginian controlled the presidency most of these years.

The key institution for maintaining state sovereignty for Virginians was the local judicial system supported by a local militia. ${ }^{36}$ In addition to the Bill of Rights, the Judiciary Act of 1789 gave broad judicial powers to states. The boundaries of federal district courts were based on state boundaries. Most importantly, section 34 of the 1789 act dictated that federal judges rely on state rather than federal decisions on comparable points of law. While the Supreme Court gradually established its rights of jurisdiction, Virginia strongly resisted these attempts through the nineteenth century. ${ }^{37}$

V. Evaluating the Causes of Institutional Divergence in the United States

Why did political institutions diverge between Virginia and Massachusetts during the colonial period? Why did the legal institutions between these two states diverge in the early nineteenth century? While it is challenging to identify the causes of institutional divergence based on the experience of two colonies (states), the histories of Massachusetts and Virginia shed valuable insights on why institutions diverged between the U.S. North and South. This study suggests that historical accidents, climate and factor endowments all were important contributing factors in the divergence of U.S. northern and southern institutions.

\footnotetext{
${ }^{36}$ In the debate over the Constitution, the antifederalists feared that a centralization of power of the government achieved through standing armies in peace time would create an arbitrary, powerful, and despotic government. See Edling (2003).

${ }^{37}$ Miller (1994, 1-2): “In 1816, Supreme Court Justice Joseph Story handed down the opinion in Martin v. Hunter's Lessee. The Court claimed appellate jurisdiction over state courts on all matters touching federal law, and asserted the authority to reverse Virginia's highest court on a question concerning state law. This was one of the most important precedents for nationalism set down by the Marshall Court. But, it was denounced in Virginia, and the judiciary refused to carry out the decision. The state's highest court declared that the Supreme Court did not have appellate jurisdiction over state courts, and the state legislature agreed... A number of Virginians were important in developing what became known as the Virginia doctrine, including William Branch Giles, Thomas Jefferson, James Madison, Edmund Pendleton, John Randolph, Spencer Roane, and John Taylor.”
} 
The initial differences in the private goals and strategies of the Virginia and Massachusetts companies led to major differences in their demographic characteristics and their early governing institutions. In Virginia, the goal of using plantation labor for profit led to a stratified demographic structure conducive to military rule. By contrast, in Massachusetts, the goal of establishing religious communities led to a homogenous, egalitarian population structure conducive to the rise of democratic government. Whereas the immigrants to Massachusetts had generally enjoyed common law rights in England and were familiar with the English county or borough judicial system, the majority of the Virginia immigrants, composed of servants and convicts, was denied these rights in England. Thus, the divergence of the early political institutions in Massachusetts and Virginia had English precedence (Konig (1982)).

Climatic differences of the American colonies contributed to the continued divergence of demographic structures and institutions in Virginia and Massachusetts. In Virginia, due to the extremely high mortality rates until the eighteenth century, there was a constant turnover of young, male servant population. ${ }^{38}$ The unbalanced sex-ratios and stratified demographic structure were not conducive to the introduction of a full-fledged democratic government in Virginia. As mortality rates stabilized and as increasing numbers of servants survived to form a sizeable population of free whites, an element of democracy was introduced in the form of the election of the Houses of Burgesses. Despite this change, however, as all other important offices were appointed, often for life, the elites were able to effectively control the government of Virginia. In Massachusetts, the low rates of mortality and low rates of immigration contributed the emergence of stable communities. After the early years, no sizeable numbers of new

\footnotetext{
${ }^{38}$ Life expectancy at birth in Ipswich, Hingham, Salem, Andover towns in Massachusetts in the seventeenth and eighteenth centuries were 55, 45, 35-37, 47-59, respectively. Life expectancy in Charles Parish and Middlesex County Virginia in the late seventeenth century were 7-8 and 15-22, respectively. Conversely, the crude death rate was significantly higher in Virginia than in Maryland. See Gemery (2000)).
} 
immigrants were introduced. The stable, egalitarian demographic structure fostered the extension of democracy to many levels of government.

Factor endowments contributed to the divergence in economic and landholding structures which influenced the final development of institutional structures in the two colonies. In Massachusetts, a climate conducive to small scale farming contributed to egalitarianism and democracy. In Virginia, a climate conducive to tobacco plantations, led to the rise of plutocracy based on the political power of the landed gentry class. In Massachusetts, there was little economic incentive to accumulate large holdings of land the method of distributing land through town governments raised the costs of land accumulation. In Virginia, the land intensive tobacco farming provided significant incentive to acquire land and the headright system lowered the costs of accumulating large landholdings by elites.

The limits of state military capacity and the possibility of rebellion by the general population also played major roles in determining the structure of American colonial governments. In Massachusetts, democracy did not arise because the elites promoted it as an ideal form of government. Rather, the elites believed that democracy would lead to mob rule. Democracy emerged, in part, as the ruling elites were forced to grant electoral concessions to the general population under a constant threat of rebellion. In 1631, when taxes were imposed on the residents of Watertown to pay for the fortification of Newtown by an elite legislative body of “assistants,” the Watertown residents rebelled against what they believed was taxation without representation. In 1632, fearing outbreaks in other towns, the “assistants” called for the election of two freemen from each town to meet with them and discuss the question of raising funds by taxation. As theorized by Acemoglu and Johnson (2002), these electoral concessions served as a 
credible commitment to a fair allocation of resources by the ruling state and were given to avert a mass rebellion.

In Virginia, the only elected office was the Houses of Burgesses. Because the elections were held at the discretion of the governor and all remaining offices, including important local offices such as sheriffs, were appointed, the elites had far greater control of the governing structure of Virginia. One reason for the political dominance of the landed elites was that, except for few brief episodes like the Bacon's rebellion, the threat of rebellion by the masses was much lower in Virginia. Because the population in Virginia was much more dispersed and few towns existed, the costs of organizing a rebellion was much higher. More importantly, most free whites who were servants were not qualified for public office and the poor often relied on the landed elites for capital as well as marketing and retail services. With the rise of slavery, the incentives of all whites became much more aligned against African slaves. Finally, the elites were able to develop a better military organization under their control to subdue uprisings.

Legal institutions diverged only slightly between Massachusetts and Virginia during the colonial period since the English common law based on local jury law served both communities relatively well. Common law and the primacy of the local jury were consistent with the system of local militia. Since local juries ruled on law and fact, local juries defined law for their local communities. Given the limited military power of the state, the governing by a militia system dictated a legal system based on local consensus and fairness. Ordering a militia to enforce a legal decision that violated a community's sense of fairness was difficult at best. ${ }^{39}$

\footnotetext{
${ }^{39}$ Nelson (1975, 34-5): "Even if judges had been inclined to ignore precedent and to overrule jury decisions on questions of law, it is doubtful whether they could have enforced their judgments. The crucial fact about government in pre-Revolutionary Massachusetts was that subordinate officials like sheriffs, deputy sheriffs, and constables - the men with legal responsibility of enforcing judgments - could do so only when local communities were willing to permit judgments to be enforced... The basic problem was that if an official failed by himself to coerce a recalcitrant person he could not call for the aid of a substantial body of force other than his fellow townsmen, organized as the militia; if the townsmen were on the side of the recalcitrant person, they would not, of course, aid the official.”
} 
In the early nineteenth century, legal institutions in Virginia and Massachusetts diverged. In Virginia, planter gentry who controlled Virginia had great incentives to keep the legal institution based on common law and local juries as protection from arbitrary powers of a more centralized government. In Massachusetts, however, the argument that local juries ensured protection against the arbitrary use of powers by the state weakened. To the contrary, the full power to establish laws, statutes, and ordinances, provided that they are not repugnant to the Constitution, including the power to modify or repeal common law, was explicitly granted to the jurisdiction of the legislature. ${ }^{40}$ Because democratic elections limited the arbitrary powers of the government, the people of Massachusetts favored a stronger centralized state government with a strong state military powers to enforce its laws.

\section{Conclusion}

This paper investigates the nature and causes of the divergence of political and legal institutions between Massachusetts and Virginia. In the colonial period, democracy arose in Massachusetts which fostered dynamism and long-run development, whereas in Virginia, an oligarchy emerged which favored status quo and agrarianism. In the early nineteenth century, as trade and industry developed in Massachusetts, instrumental, uniform state-wide law emerged, whereas in Virginia, traditional common law and local juries remained the primary basis for ensuring local control of society. The analysis of this paper suggests that a variety of factors,

\footnotetext{
${ }^{40}$ Nelson (1975, 92): "New ideas about the relationship between government and the governed also produced changes in the rules of law concerning the rights and liabilities of various public officials. The perception that officials were agents of the people rather than of some distant, arbitrary governor raised doubts about the continuing validity of colonial rules holding officials strictly accountable for the infringements on liberty and for other low doings... Such thinking led to a number of changes that reduced the liability of officials in common law actions for damages."
} 
such as historical accidents, climate, factor endowments, and military capacity of the state, all contributed to the divergence of political and legal institutions in Virginia and Massachusetts.

It was also important that Virginia and Massachusetts were settled by the English with the Anglo-Saxon common law rather than the Roman civil law tradition. Unlike civil law, a system of positive rules codified in books called codes, the English common law had a two-tier system: the King's court of chancery and the common law courts. Whereas the law of equity from chancery evolved into a complex body of rules understood by trained lawyers and judges, the common law for common people was based on local tradition, custom and precedents (Hall (1989)). In the American colonies, this common law heritage combined with local methods of selecting judges reinforced the development of localism and divergence (Ely and Bodenhamer (1986)).

The founding of American colonies in the seventeenth century provides a valuable historical experiment in the development of political and legal institutions in a new world. Even though the American colonies were established to extend the territory of the British Empire, distance and circumstances forced these colonies to develop their own governing institutions and seek independence over time. While the histories of Massachusetts and Virginia yield important clues as to why institutions diverged between the U.S. North and South, a fuller picture of the causes of institutional developments in the New World will no doubt emerge with additional investigations of the histories of the other eleven colonies. 


\section{References}

Acemoglu, Daron and James A. Robinson. 2000. "Why Did the West Extend the Franchise? Democracy, Inequality, and Growth in Historical Perspective,” Quarterly Journal of Economics 115: 1167-1199.

Acemoglu, Daron and James A. Robinson. 2006. "Persistence of Power, Elites and Institutions," NBER Working Paper 12108.

Acemoglu, Daron, Simon Johnson and James A. Robinson. 2001. "The Colonial Origins of Comparative Development: An Empirical Investigation,” American Economic Review 91: 1369-1401.

Acemoglu, Daron, Simon Johnson and James A. Robinson. 2002. "Reversal of Fortunes: Geography and Institutions in the Making of the Modern World Income Distribution," Quarterly Journal of Economics 117: 1231-1294.

Acemoglu, Daron, Simon Johnson and James A. Robinson. 2004. “Institutions as the Fundamental Cause of Long-run Growth,” mimeo.

Akagi, Roy H. 1924. The Town Proprietors of the New England Colonies: A Study of Their Development, Organization, Activities and Controversies, 1620-1770. University of Pennsylvania Press.

Allen, David G. 1981. In English Ways: The Movement of Societies and the Transfer of English Local Law and Custom to Massachusetts Bay in the Seventeenth Century. University of North Carolina Press.

Alston, Lee J. and Morton O. Shapiro. 1984. "Inheritance Laws Across the Colonies: Causes and Consequences,” Journal of Economic History 44 (2): 277-287.

Andrews, Charles M. 1934. The Colonial Period of American History: The Settlements, Volume 1. New Haven: Yale University Press.

Beer, George L. 1908 [1959 reprint]. The Origins of the British Colonial System 1578-1660. Gloucester: Peter Smith.

Berkowitz, Daniel and Karen Clay. 2006. The Effects of Judicial Independence on Courts: Evidence from the American States. Journal of Legal Studies.

Breen, T. H. 1970. The Character of the Good Ruler: Puritan Political Ideas in New England 1630-1730. New Haven: Yale University Press.

Brewer, Holly. 1997. "Entailing Aristocracy in Colonial Virginia: 'Ancient Feudal Restraints' and Revolutionary Reform,” William and Mary Quarterly 54: 307-346.

Brown, Robert E. and B. Katherine Brown. 1964. Virginia 1705-1786: Democracy or Aristocracy? Michigan State University Press.

Bushman, Richard L. 1985. King and People in Provincial Massachusetts. University of North Carolina Press.

Campbell, Bruce A, 1975. “John Marshall, the Virginia Political Economy, and the Dartmouth Decision,” American Journal of Legal History, 19: 40-65.

Cook, Edward M. 1976. The Fathers of the Town: Leadership and Community Structure in Eighteenth-Century New England. Johns Hopkins University Press.

Craven, Wesley F. 1970. The Southern Colonies in the Seventeenth Century 1607-1689. Louisiana State University Press.

Cress, Lawrence D. 1982. Citizens in Arms: The Army and the Militia in American Society to the War of 1812. University of North Carolina Press. 
Daniels, Bruce C. 1983. Dissent and Conformity on Narragansett Bay. Wesleyan University Press.

Easterlin, Richard. 1960. "Interregional Differences in Per Capita Income, Population, and Total Income, 1840-1950.” In Trends in the American Economy in the Nineteenth Century, edited by William Parker. Princeton University Press.

Easterly, William and Ross Levine. 2002. "Tropics, Germs, and Crops: How Endowments Influence Economic Development,” NBER Working Paper \#9106, 2002.

Egnal, Marc. 1996. Divergent Paths: How Culture and Institutions Have Shaped North American Growth. Oxford University Press.

Ely, James W. and David J. Bodenhamer. 1984. "Regionalism and the Legal History of the South,” in Ambivalent Legacy: A Legal History of the South, edited by D. Bodenhamer and J. Ely, University Press of Mississippi.

Easterlin, Richard. 1960. "Interregional Differences in Per Capita Income, Population, and Total Income, 1840-1950,” In Trends in the American Economy in the Nineteenth Century, edited by William Parker. Princeton University Press.

Edling, Max M. 2003. A Revolution in Favor of Government: Origins of the U.S. Constitution and the Making of the American State. Oxford University Press.

Engerman, Stanley L. and Kenneth L. Sokoloff. 1997. "Factor Endowments, Institutions, and Differential Paths of Growth Among New World Economies: A View From Economic Historians of the United States,” in How Latin America Fell Behind: Essays on the Economic Histories of Brazil and Mexico 1800-1914. Stanford University Press.

Engerman, Stanley L. and Kenneth L. Sokoloff. 2000. "Institutions, Factor Endowments, and Paths of Development in the New World," Journal of Economic Perspectives 14 (3): 217232.

Fogel, Robert W. 1989. Without Consent or Contract. W.W. Norton.

Friedman, Lawrence M. 1973. A History of American Law. Simon and Schuster.

Friedman, Lawrence M. 1984. "The Law Between the States: Some Thoughts on Southern Legal History,” in Ambivalent Legacy: A Legal History of the South, edited by D. Bodenhamer and J. Ely, University Press of Mississippi.

Gemery, Henry. A. 2000. “The White Population of the Colonial United States 1607-1790,” in A Population History of North America, edited by M. Haines and R. Steckel. Cambridge: Cambridge University Press.

Glaeser, Edward L. and Andrei Shleifer. 2002. “Legal Origins,” Quarterly Journal of Economics 117: 1193-1230.

Griffith, Lucille. 1970. The Virginia House of Burgesses, 1750-1774. Revised Edition. University of Alabama Press.

Groebel, Julius. 1931. "King's Law and Local Custom in Seventeenth-Century New England,” Columbia Law Review 31: 416-.

Hall, Kermit L. 1989. The Magic Mirror: Law in American History. Oxford University Press. Haskins, George L. 1960. Law and Authority in Early Massachusetts. MacMillan Co..

Higginbotham, A. Leon. 1978. In the Matter of Color: Race and the American Legal Process, The Colonial Period. Oxford: Oxford University Press.

Hindus, Michael S. 1980. Prison and Plantation: Crime, Justice, and Authority in Massachusetts and South Carolina, 1767-1878. University of North Carolina Press.

Horowitz, Morton J. 1977. The Transformation of American Law 1780-1860. Harvard University Press. 
Huebner, Timothy S. 1999. The Southern Judicial Tradition: State Judges and Sectional Distinctiveness, 1790-1890. University of Georgia Press.

Hughes, Jonathan and Louis Cain. 2003. American Economic History, Sixth Edition. Boston: Addison Wesley.

Hurst, James W. 1956. Law and the Conditions of Freedom in the Nineteenth-Century United States. University of Wisconsin Press.

Hyman, Harold M. and William M. Wiecek. 1982. Equal Justice Under Law: Constitutional Development 1835-1875. Harper \& Row.

Innes, Stephen. 1983. Labor in a New Land: Economy and Society in Seventeenth-Century Springfield. Princeton University Press.

Jones, Alice H. 1980. Wealth of a Nation To Be: American Colonies on the Eve of the Revolution. Columbia University Press.

Karras, Alan L. 1992. Sojourners to the Sun: Scottish Migrants in Jamaica and the Chesapeake, 1740-1800. Cornell University Press.

Kars, Marjoleine. 2002. Breaking Loose Together: The Regulator Rebellion in PreRevolutionary North Carolina. University of North Carolina Press.

Keim, C. Ray. 1968. "Primogeniture and Entail in Colonial Virginia,” William and Mary Quarterly 25:

Key, V. O. 1977. Southern Politics in State and Nation: A New Edition. Knoxville: University of Tennessee Press.

Kim, Sukkoo. 1998. “Economic Integration and Convergence: U.S. Regions, 1840-1990,” Journal of Economic History 58: 659-683.

Kim, Sukkoo. 2007. "Spatial Inequality and Development: Theories, Facts and Policies,” mimeo.

Kim, Sukkoo and Robert Margo. 2004. "Historical Perspectives on U.S. Economic Geography," in Handbook of Regional and Urban Economics, Volume 4, J. V. Henderson and J-F. Thisse, editors. North Holland.

Konig, David T. 1979. Law and Society in Puritan Massachusetts Essex County, 1629-1692. University of North Carolina Press.

Konig, David T. 1992. "The Virgin and the Virgin's Sister: Virginia, Massachusetts, and the Contested Legacy of Colonial Law,” in The History of Law In Massachusetts: The Supreme Judicial Court 1692-1992 edited by R. Osgood, Supreme Judicial Court Historical Society, 1992.

Kulikoff, Allan. 1986. Tobacco and Slaves: The Development of Southern Cultures in the Chesapeake, 1680-1800. University of North Carolina Press.

La Porta, Rafael, Florencio Lopez de Silanes, Andrei Shleifer, and Robert Vishney. 1998a. "Law and Finance,” Journal of Political Economy 106 (6): 1113-1155.

La Porta, Rafael, Florencio Lopez de Silanes, Andrei Shleifer, and Robert Vishney. 1998b. “Quality of Government,” Journal of Law, Economics and Organization 15 (1-2): 3-27.

Majewski, John. 2000. A House Dividing: Economic Development in Pennsylvania and Virginia Before the Civil War. Cambridge University Press.

Mann, Bruce H. 1987. Neighbors and Strangers: Law and Community in Early Connecticut. University of North Carolina Press.

Martin, John F. 1991. Profits in the Wilderness: Entrepreneurship and the Founding of New England Towns in the Seventeenth Century. University of North Carolina Press.

Mathews, Lois K. 1962. The Expansion of New England: The Spread of New England Settlement and Institutions to the Mississippi River 1620-1865. Russel \& Russell. 
McDonald, Forrest. 1985. Novus Ordo Seclorum: The Intellectual Origins of the Constitution. University Press of Kansas.

McDonald, Forrest. 2000. States’ Rights and the Union: Imperium in Imperio 1776-1876. University Press of Kansas.

Meinig, D.W. 1993. The Shaping of America: Continental America 1800-1967. Volume 2. Yale University Press.

Miller, F. Thornton. 1994. Juries and Judges Versus the Law: Virginia's Provincial Legal Perspective, 1783-1828. University Press of Virginia.

Mitchener, Kris and Ian McLean. 1999. "U.S. Regional Growth and Convergence, 1880-1980," Journal of Economic History 59: 1016-1042.

Mitchener, Kris and Ian McLean. 2003. “The Productivity of U.S. States Since 1880,” Journal of Economic Growth 8: 73-114.

Morgan, Edmund S. 1975. American Slavery American Freedom: The Ordeal of Colonial Virginia. W.W. Norton \& Co..

Morris, Thomas D. 1996. Southern Slavery and the Law 1619-1860. Chapel Hill: University of North Carolina Press.

Nelson, William E. 1975. Americanization of the Common Law: The Impact of Legal Change on Massachusetts Society, 1760-1830. Harvard University Press.

Nelson, William E. 1981. Dispute and Conflict Resolution in Plymouth County, Massachusetts, 1725-1825. University of North Carolina Press.

North, Douglass C. 1981. Structure and Change in Economic History. W.W. Norton \& Company.

North, Douglass C. 1990. Institutions, Institutional Change and Economic Performance. Cambridge University Press.

North, Douglass C. and Barry R. Weingast. 1989. "Constitutions and Commitment: The Evolution of Institutions Governing Public Choice in Seventeenth-Century England," Journal of Economic History 49 (4): 803-832.

Osgood, Herbert L. 1904. The American Colonies in the Seventeenth Century, Volume 1. Macmillan Company.

Oesterle, Dale A. 1992. "Formative Contributions to American Corporate Law by the Massachusetts Supreme Judicial Court from 1806 to 1810," in The History of Law In Massachusetts: The Supreme Judicial Court 1692-1992 edited by R. Osgood, Supreme Judicial Court Historical Society.

Porter, Albert O. 1947. County Government in Virginia: A Legislative History, 1607-1904. Columbia University Press.

Powell, Sumner C. 1963. Puritan Village: The Formation of a New England Town. Wesleyan University Press.

Price, Edward T. 1995. Dividing the Land: Early American Beginnings of Our Private Property Mosaic. University of Chicago Press.

Priest, Claire. 2006. "Creating an American Property Law: Alienability and Its Limits in American History,” Harvard Law Review

Roeber, A. G. 1981. Faithful Magistrates and Republican Lawyers: Creators of Virginia Legal Culture, 1680-1810. University of North Carolina Press.

Rothenberg, Winifred B. 1992. From Market-Places to a Market Economy: The Transformation of Rural Massachusetts 1750-1850. University of Chicago Press. 
Rutman, Darrett B. 1965. Winthrop's Boston: A Portrait of a Puritan Town, 1630-1649. University of North Carolina Press.

Scheiber, Harry. 1973. "Property Law, Expropriation, and Resource Allocation by Government: the United States, 1789-1910,” Journal of Economic History 33 (1): 232-251.

Scheiber, Harry. 1975. "Instrumentalism and Property Rights," Wisconsin Law Review.

Schwartz, Gary T. 1981. "Tort Law and the Economy in Nineteenth-Century America: A Reinterpretation,” Yale Law Journal 90, 8:

Shea, William L. 1983. The Virginia Militia in the Seventeenth Century. Louisiana State University Press.

Simmons, R. C. 1976. The American Colonies From Settlement to Independence. W.W. Norton \& Company.

Simpson, A.W.B. 1979. "The Horwitz Thesis and the History of Contracts,” University of Chicago Law Review, 46, 3: 533-601.

Steckel, Richard. 1983. “The Economic Foundations of East-West Migration during the Nineteenth Century.” Explorations in Economic History 20: 14-36.

Steinberg, Theodore. 1991. Nature Incorporated: Industrialization and the Waters of New England. Cambridge: Cambridge University Press.

Sydnor, Charles S. 1948. The Development of Southern Sectionalism 1819-1848. Louisiana State University Press.

Sydnor, Charles S. 1952. American Revolutionaries in the Making: Political Practices in Washington's Virginia. Free Press.

Tushnet, Mark. 1981. The American Law of Slavery 1810-1860: Consideration of Humanity and Interest. Princeton: Princeton University Press.

Wahl, Jenny B. 1998. The Bondsman's Burden: An Economic Analysis of the Common Law of Southern Slavery. Cambridge University Press.

Wall, Robert E. 1972. Massachusetts Bay: The Crucial Decade, 1640-1650. New Haven: Yale University Press.

Wilentz, Sean. 2005. The Rise of American Democracy: Jefferson to Lincoln. W.W. Norton \& Company.

Zainaldin, Jamil. 1983. Law in Antebellum Society: Legal Change and Economic Expansion. Alfred A. Knopf. 